\title{
Sofia 1998
}

\author{
By Ron Holloway \\ Spring 1999 Issue of KINEMA
}

\section{THIRD SOFIA FESTIVAL OF EUROPEAN COPRODUCTIONS}

Without the Sofia Festival of European Coproductions -- in itself, a rather unique film event on the festival calendar -- there might not have been a revival of Bulgarian cinema at all. The festival, launched in 1996 as "Days of European Cinema" closely on the heels of Cannes, included among a diverse array of European films a half-dozen productions that had either been produced at the local Boyana Studios or could be listed by virtue of services-rendered as legitimate Bulgarian coproductions. That initial festival spotlighted no less than nine Bulgarian co-productions, among these the film that was to compete a few weeks later at Moscow and then was selected to open the Mannheim-Heidelberg festival: Georgi Dyulgerov's Black Swallow (BulgariaFrance). Story elements as Orthodox belief, Moslem presence, traditional gypsy rituals, and post-communist hangovers. This remarkably honest and spiritually profound film about the fate of beautiful Magdalena, a gypsy girl from the villages in love with a mute shepherd, moralizes on the question as to whether ethic groups can continue to live peacefully together in the Balkans. This year, at the 3rd Festival of European co-productions (June 5-11) -- now primed to computerized perfection by Kalina Wagenstein and Gergana Dukovska of the Bulgarian National Film Center in collaboration with nine other prominent national film and cultural agencies (including the ever-present Soros sponsored "Open Society" Foundation) -- the program highlighted international award-winners. Despite the distraction of the World Cup, audiences turned out in heavy numbers at the Lumière Hall in the National Palace of Culture for Patrice Leconte's Ridicule (France), Alain Berliner's Ma vie en rose (Belgium-Switzerland-France-Great Britain), Marleen Gorris's Antonia's Line (Belgium-Netherlands-Great Britain), Bence Gyööngyöössy's Gypsy Lore (Hungary-Germany-Bulgaria), and (most appropriate of all for the festival portfolio) Regina Ziegler's series of six short Erotic Tales co-produced in as many European countries: Nicolas Roeg's Hotel Paradise (Great Britain), Cinzia Torrini's Caramella (Italy), Jos Stelling's The Waiting Room (Netherlands), Janusz Majewski's Devilish Education (Poland), Mika Kaurismäki's Sambolico (Finland), and Detlev Buck's Elephants Never Forget (Germany). True, New Bulgarian Cinema has yet to make its presence known at international film festivals as in days past. But much of the blame can be put on parliamentary infighting among multiple political parties, the disastrous economic policies of the post-communist government, and an unfortunate lack of marketing finesse for what has been accomplished, despite all, by a handful of veteran name directors: Rangel Vulchanov, Georgi Dyulgerov, Kiran Kolarov, Yevgeni Michailov (presently the head of Boyana Studios), and cameraman-turned director Radoslav Spassov (secretary of the Union of Bulgarian Filmmakers). To dramatize the obvious to the point of absurdity, how many cineastes know that both the Golden Palm at Cannes, Emir Kusturica's Underground, and the Golden Lion at Venice, Milcho Manchevski's Before the Rain, were completed with a significantservices-rendered input at the Boyana Studios? During the difficult 1990s, an inventive policy of "services-rendered" has become the lifeline of the Boyana Studios. Whereas in the 1980s as many as 3,000 workers had been employed at the studios, today only 240 film professionals are needed. Gone is the biannual animation festival in Varna on the Black Sea, while those awarded masters of Bulgarian animation -- Donyo Donev, Todor Dinov, Henri Kulev -- have either emigrated abroad or are teaching in the local Academy of Arts. Documentary filmmakers, once the pride of Leipzig and Oberhausen, are delivering mostly video productions to public and private TV stations. Before 1989, the Boyana Studios produced 15 to 20 feature films annually; today, only two or three are released -- and these primarily via the co-production route. What generally caused the downfall of Bulgarian cinema need not be repeated here. Suffice it to say that news reports have focused at some length on corruption in the post-communist government and the plundering of resources by a growing mafia web. The situation inside the film industry was once described by a knowledgeable critic as catastrophic: he remarked that even state subsidies approved by the government for national film projects never seemed to reach the respective producers and directors intended. Under the new government, led by Petar Stoyanov with the backing of a coalition of democratic parties, the National Film Center under Dimitar Dereliev will play a key role in the revival of Bulgarian cinema. One major step towards a revitalized national cinematography was the founding of the Festival of European Coproductions 
three years ago. Of course, its primary aim is to bring quality European film production to a public sated with "Hollywood B-movies." But it is also geared to encourage international coproductions and to support promising national productions. At the Boyana Studios, reorganized under the new management of film director Yevgeni Michailov (Canary Season, 1993), services have been rendered in the recent past to a dozen major productions, including Bernardo Bertolucci's Little Buddha and Marco Bellochio's The Prince of Homburg, while Michael Cacoyannis's screen adaptation of Chekhov's The Cherry Orchard is about to make use the facilities. And award-winning animation director Zlatin Radev (Shock, 1993) has recently signed a contract with Canadian television to produce an animation series, which, in turn, will help to train a new generation of graphic artists. Most significant of all, Duga Art Film, a private company founded in 1992 under Verginia Arsova, has risen in a short time to become the trusted distribution arm in Bulgaria for 20th Century Fox, New Line Cinema, Canal+ France, and other European companies. With offices in Sofia, Varna, and Plovdiv, it expanded its exhibition chain this summer by converting an ancient Greek arena (dating from Philip of Macedonia) into an outdoor theater for a summer film festival. Via Ivanka Grubcheva, one of Eastern Europe's best known woman filmmakers, the company has links as well to the Union of Bulgarian Filmmakers. Drawing upon its distribution and exhibition resources, Duga Art Film now plans a slate of Bulgarian productions for the national audience. That a domestic audience does indeed thirst for national production has already been proven. Since last January, a series of "Bulgarian Film Classics" have aired to high viewing ratings each Monday night, often soaring over the million mark. "It's only a matter of time," predicts Dimitar Dereliev, "before Bulgarian cinema will become a regular event on both the national and international stage."

\section{Author Information}

Ron HOLLOWAY (1933-2009) was an American critic, film historian, filmmaker and correspondent who adopted Europe as his home in the early fifties and spent much of his life in Berlin. He was an expert on the study of German cinema and against all odds produced, with his wife Dorothea, the journal German Film, keeping us up-to-date with the work of directors, producers and writers and the showing of German films around the world.

In 2007, Ron Holloway and his wife were awarded the Berlinale Camera Award. Ron also received the Bundesverdienstkreuz (German Cross of Merit), Polish Rings, Cannes Gold Medaille, the American Cinema Foundation Award, the Diploma for Support of Russian Cinema and an honorary award from the German Film Critics' Association.

Ron was also a valued contributor to Kinema for the past fifteen years. 